\title{
David versus Goliath - The resistance of non-humans in the translation process: the case of the new coronavirus disinteressement
}

\author{
EDUARDO GUEDES VILLAR ${ }^{1}$ \\ KARINA DE DÉA ROGLIO ${ }^{2}$ \\ Marcos VinícIUS PEREIRA CORREA ${ }^{3}$ \\ RODRIGO SEEFELD ${ }^{2}$ \\ ${ }^{1}$ Universidade Regional de Blumenau (FURB), Blumenau - SC, BRAZIL \\ 2 Universidade Federal do Paraná (UFPR), CURITIBA - PR, BRAZIL \\ ${ }^{3}$ Universidade Estadual do Paraná (UNESPAR), PARANAguá - PR, BRAZIL
}

\begin{abstract}
Based on the sociology of translation, we studied the extreme case of the new coronavirus to explore the role of non-humans in relational processes. We seek to understand how leaders of three countries tried, in a translation process, to take the voice of the new coronavirus and how the virus resisted the imposition of roles by the human actors of the study. Through the analysis of the leaders' statements, interviews, and social media posts, we suggested the process of disinteressement, in four movements. As a contribution, we show how the non-human actant (i) is active in terms of participation in the translation process, and (ii) resisted the roles imposed.
\end{abstract}

Keywords: Non-human actants. Disinteressement. COVID-19 Pandemic. Sociology of Translation.

Davi versus Golias - A resistência dos não-humanos no processo de tradução: o caso do desinteressamento do novo coronavírus

\section{Resumo}

Com base na sociologia da tradução, estudamos o caso extremo do novo coronavírus para explorar o papel dos não-humanos nos processos relacionais. Procuramos compreender como líderes de três países tentaram, num processo de tradução, tomar a voz do novo coronavírus, e como o vírus resistiu à imposição de papéis por parte dos atores humanos do estudo. Por meio da análise de declarações, entrevistas e postagens em mídia social destes líderes, sugerimos o processo de desinteressamento, em quatro movimentos. Como contribuição, mostramos como o agente não humano (i) é ativo em termos de participação no processo de tradução, e (ii) possui recalcitrância, pois resistiu aos papéis que lhe foram impostos.

Palavras-chave: Atuantes não humanos. Desinteressamento. Pandemia da COVID-19. Sociologia da Tradução.

David contra Goliat - La resistencia de los no humanos en el proceso de traducción: el caso del desinterés por el coronavirus

\section{Resumen}

Basándonos en la sociología de la traducción, estudiamos el caso extremo del nuevo coronavirus para explorar el papel de los no humanos en los procesos relacionales. Intentamos entender cómo los líderes de tres países intentaron, en un proceso de traducción, tomar la voz del nuevo coronavirus, y cómo el virus resistió a la imposición de roles por parte de los actores humanos en el estudio. A través del análisis de declaraciones, entrevistas y publicaciones en redes sociales de estos líderes, sugerimos el proceso de desinterés, en cuatro movimientos. Como aporte, mostramos cómo el agente no humano (i) es activo en cuanto a participación en el proceso de traducción, y (ii) es recalcitrante, porque resistió los roles que le fueron impuestos.

Palabras clave: Actores no humanos. Desinterés. Pandemia de COVID-19. Sociología de la traducción. 


\section{INTRODUCTION}

"This will end with humanity victorious over yet another virus, there's no question about that" (Bruce Aylward, Advisor to WHO Director-General, 2020).

"The epidemic is faster than our bureaucracy" (Angelo Borelli, Head of Italian Civil Protection, 2020).

"This virus does not negotiate with anyone. It does not pay attention to anyone. All the people who stood in its way, were overcome by the virus" (Luiz Henrique Mandetta, Former Minister of Health of Brazil, 2020).

The recent action of the SARS-CoV-2 (new coronavirus hereafter), although tragic in its effects (Ali, 2020), is a chance to investigate the participation of non-human actants on the organizational arrangements of different social systems. In particular, the translation effort to establish a role for it and speak on its behalf. According to Callon (1986, p. 14), speaking on behalf of entities that do not have a clear language (e.g., new coronavirus), supposes "the need for continuous, infinitely more sophisticated adjustments and devices of interest".

The new coronavirus was first identified on December 31, 2019, in Wuhan, in the Republic of China (World Health Organization [WHO], 2020). On March 11, 2020, the high spread of the virus and the severity of the disease it causes, led the World Health Organization (WHO hereafter) to declare the COVID-19 (respiratory illness caused by the new coronavirus) as a pandemic (WHO, 2020). Since then, the new coronavirus has caused transformations in people's lives and had social, economic, political and cultural repercussions in the most diverse social systems.

In organization studies, despite the relative acceptance of the role and participation of non-humans (e.g., actifacts, tools, theories) (Woolgar, Coopmans \& Neyland, 2009), the investigations are still substantially centred on the human being (i.e. absence of symmetry) or consider a questionable (unreal) relationship between humans and non-humans (i.e. absurd symmetry) (McLean \& Hassard, 2004). In addition, the studies naively explored the participation of non-humans in their instrumental or conditioned use (Law \& Singleton, 2005). As Latour (2000, p. 117) states "the things are unfairly accused of being just "things'".

In this study, we seek to understand how the leaders of three countries (Brazil, Italy and the United States) tried, in a translation process, to take the voice of the new coronavirus; and how the virus resisted the imposition of roles by these leaders. Latour (1992) suggests that making the small (e.g., new coronavirus) stronger than the large (e.g., states, governments and macro-actors), is not only a question of analytical symmetry but certainly also a moral issue, as in the story of David and Goliath.

Based on actor-network theory (ANT hereafter) (Blok, Farias \& Roberts, 2020; Latour, 2005), we adopted the lens of the sociology of translation which makes room for a deeper analysis of the participation of non-humans (e.g., Cochoy, 2014). This perspective allows to understand the process of production and stabilization of human and non-human entities in heterogeneous systems of relations (Alcadipani \& Hassard, 2010; Lee \& Hassard, 1999).

We theoretically explain a case of disinteressement ${ }^{1}$, in which the translation process does not occur so human-oriented or politically well-adjusted, or still, does not reach a well-stabilized and convergent "end" as suggested by Callon (1986). In the disinteressement process - in opposition to the interessement (Akrich, Callon, Latour \& Monaghan, 2002) - we show how the virus relationally resisted the offensives of human actors in an attempt to impose roles and identities to it.

\section{LITERATURE REVIEW}

In ANT, there is an ontological change to understand the social (Lee \& Hassard, 1999; Tonelli, 2016), based on the idea that society is composed, made, built, stabilized, maintained, (re)assembled and challenged (see Latour, 2005 for an exceptional explanation). Furthermore, the social cannot be taken as a source of causality that explains the existence and stability of some other action or behaviour (Cavalcanti \& Alcadipani, 2013; Law, 1992). Therefore, the participation of humans and non-humans

\footnotetext{
${ }^{1}$ To maintain the same etymological sense of the term interessement (detailed afterwards), we adapted from the French term désintéressement.
} 
in analytical symmetry is recognized to understand how the relationships between them are translated, that is, how some types of entities come to represent others (Greener, 2006).

It is important to note that the term actant indicates anything that acts in the relational system, and actor means "what is made the source of an action" (Latour, 1992, p. 177). By adopting these terms in their semiotic meaning, they are not limited only to human beings and, therefore, have no relation with the sociological definition of the term actor, as opposed to mere behaviour (Latour, 2005). In this sense, by considering multiple voices that make up the relational fabric of an actor-network, the analysis is extended beyond an anthropocentric understanding of reality (Latour, 2004).

Thus, the sociology of translation, as a prominent research line of the ANT (Wæraas \& Nielsen, 2016), helps to explain innovatively the relations in challenging environments (Luoma-aho \& Paloviita, 2010). In other words, it allows a broader and symmetrical understanding of the arrangement of networks and their (trans)formations, by (i) emphasizing the importance of negotiating roles, identities and interests (through translation processes) and (ii) recognizing non-human actants as essential parts of these processes.

Callon (1986) theorized the translation process by analyzing the relations among multiple actacts such as researchers, fishermen, collectors and scallops in the Bay of Saint-Brieuc in France. Due to a series of unpredictable displacements, the author systematically described the translation process and detailed the role of all actants (human and non-human) involved as a result of various relational transformations. In this sense, the translation goes beyond the simple substitution or representation of actors (actants) by other actors in which one simply takes the place of the other. The process involves expressing what others say and want, why they act as they do, and how they associate with each other.

Given this, Callon (1986, p. 19) affirms that to translate "is to establish oneself as a spokesman". Or simply become an actor as an effect of the relational process, wherein the identities and interests of the multiple actants are under constant negotiation and looking for stabilization (Greener, 2006). Although this stabilization is crucial for the structuring of the relations of power, there are struggles over identities and interests that can be studied empirically (Bergstrom \& Diedrich, 2011).

\section{UNVEILING THE TRANSLATION PROCESS IN ORGANIZATIONAL STUDIES}

Due to the diversity of contexts, phenomena and objectives, the translation approach has proven to be a versatile analytical lens for scholars in organizational studies (Cochoy, 2014). In a broad sense, the translation perspective allows a processual approach to a phenomenon, once it systematically involves elements in negotiation, mobilization, or transportation.

Wæraas and Nielsen (2016) identified three main developments in the sociology of translation in organizational studies: (i) actor-network theory, (ii) knowledge-based theory, and (iii) Scandinavian institutionalism. Concerning the ANT approach our focus in this study - Wæraas and Nielsen (2016) suggested that translation has three (non-exclusive and complementary) meanings, namely (i) the political meaning: the complex process of negotiation in which meanings, claims and interests change and gain ground, often involving acts of persuasion, power games and strategic manoeuvres; (ii) the geometric meaning: the mobilization of human and non-human actors in different directions; (iii) the semiotic meaning: the transformation of meaning during the movement of the network in question.

In his seminal study, Callon (1986) suggests four moments to explain the translation process, namely (i) problematization; (ii) interessement; (iii) enrolment; (iv) mobilization. Throughout this process, the identity of actors, the possibilities of interaction and the margins of manoeuvre are negotiated (Bruce \& Nyland, 2011).

At the problematization moment, Callon (1986) details the first movement of how actors become indispensable in a network to which they belong. It is assumed that there is a change in the relational system induced/motivated by (i) the participation of new entities, (ii) spatial-temporal movement and/or geometric change of the habitual relations, and (iii) the need to forge new relations. Moreover, through this relational change, a subject or an issue that disturbs (or begins to disturb) the relational system needs to be stabilized (even in a provisional stance) (Luoma-aho \& Paloviita, 2010). 
Even in an introductory manner, the aim at this first moment is to establish the actors of the network and define the identities of each one in convergence with a common understanding, that is, an obligatory passage point. In other words, this moment refers to the efforts of an actor (or some actors) to convince others to adopt their vision (Alcouffe, Berland \& Levant, 2008) and thus define the identities and interests of others, who want to get involved and speak on their behalf (Bergstrom \& Diedrich, 2011).

The second moment of translation refers to the interessement ${ }_{2}$ (Callon, 1986), in which the aim is to stabilize the actors' roles. At this point, the actors identified and the relations foreseen in the problematization moment have not yet been tested. That is, although there is a pre-planned relational scenario (from problematization), it will be tested, adjusted or refuted just at the interessement (Akrich et al., 2002). This scenario means that there is still room for previously identified entities (i) to integrate themselves into the problematized plan, or (ii) to refuse to participate (totally or partially) in the translation process, defining their identities, orientations, motivations and interests in other directions (Dambrin \& Robson, 2011).

The interessement involves, therefore, attempts by an actor (actant) to convince others that the benefits he/she/it has defined for them are in line with his/her/its own benefits (Bergstrom \& Diedrich, 2011). In this case, it is not a direct process of acceptance or refusal, and a variety of strategies and persuasion mechanisms can be adopted (Luoma-aho \& Paloviita, 2010) once the identity and "geometry" of relations can be modified throughout this moment. In general, the offensives to interest others should be seen as attempts to define and impose contingent forms of social order by a specific (set of) actor(s) (Callon \& Law, 1982).

At the enrolment moment, the third in Callon's (1986) translation process, the enroller actor seeks to define and coordinate the roles of the other actors. Enrolment, distancing itself from a functionalist viewpoint, does not imply or exclude the possibility of pre-established roles, since it designates a movement through which a set of interrelated roles are defined and assigned to the actors who accept them (Bergstrom \& Diedrich, 2011).

The enrolment moment is mainly related to how the previously proposed provisional order is achieved (Callon \& Law, 1982). The enrolled are understood as those who have had their roles and interests constructed or translated, and then come to understand the situation by the terms (e.g., roles, identities, interests, objectives) that link them to the network (Whittle \& Spicer, 2008).

The fourth moment refers to the mobilization of allies in the relational arrangement. In this movement, a series of intermediaries and equivalences leads to the designation of a spokesperson (Bergstrom \& Diedrich, 2011). By taking the voice and speaking on behalf of the various actants, the representative-actor ends up reinforcing roles, identities and objectives previously negotiated, which become a matter of indifference. Once a consensus is reached, the margins of manoeuvre of each entity will be sharply delimited.

At this final moment, "the network can act as a single unit, which can be distinguished from its environment as an object (actor-network) with its own consistent identity" (Callon \& Law, 1997, p. 170). However, its stability does not come only from the connection between elements, because each entity constitutes a network in itself so that any change in the entities of an actor-network generates transformations in the network organization itself (Sayes, 2014). Therefore, even if convergences are achieved, they are always fragile, precarious, and transitory (Greener, 2006).

The translation process does not always take place in an intended manner, or even, after a (temporarily) successful stabilization, something or someone may break through the network. For example, Bergstrom and Diedrich (2011) pointed to the movement of dissidence, in which some actants do not follow the paths (roles and identities) that have been (relatively) attributed to them. Another forms of "imperfection" in translation are (i) the counter-enrolment, based in a dispute to define the problematization around who or what the network will be mobilized (Vickers \& Fox, 2005), and (ii) the process of disentanglement, in which after a network have been mobilized, actors try to disassociate themselves from the 'made actor' that mobilized them previously (Greener, 2006).

Finally, it should be noted that rather than four separate, linearly sequenced moments, the translation approach considers the arrangement of any network a complex process with multiple, cumulative and conjunctive progressions of convergent, parallel and/or divergent activities (Alcouffe et al., 2008). The distinctions between these four moments are not given a priori immediately and do not imply an implicit temporal differentiation (Bergstrom \& Diedrich, 2011). However, as

${ }^{2}$ Callon (1986) justifies the choice of the term interessement by the etymological meaning, i.e., to be interested means 'to be between', to be filed. 
analytical heuristics or sensitizing concepts (Whittle \& Spicer, 2008), these moments help to describe the complex process by which actors/actants have been structured into a network, leading them to accept the relational system in which voices are silenced, and actors are forged (Bruce \& Nyland, 2011).

\section{METHODOLOGY}

In this investigation, we seek to explore how leaders from three countries have established relations to take the voice of the new coronavirus and speak on its behalf, what Callon (1986) called interessement. In this process of analysis, we remain attentive, in a symmetrical way, to the participation of the new coronavirus in the process of translation.

To comply with the symmetrical view, we (i) treated the new coronavirus as a social fact (Latour, 2000), (ii) approached the translation process as an exchange of properties between human and non-human actants (Hawkins, 2015), (iii) empirically followed the negotiation process of roles and identities among actants (Latour, 2005).

The new coronavirus caused a pandemic (WHO, 2020) with more than 5 million people infected in the world by May 20, 2020 and impacted on the organization of different social systems (Gudi \& Tiwari, 2020). Therefore, due to its effects, the new coronavirus becomes an extreme case of non-human participation and therefore a privileged space for theorization. In theoretical terms, the involvement of the non-human actant (i.e. new coronavirus) destabilize relations, identities and roles which remain exposed to theorizing (Latour, 2005), i.e., because they undergo modifications (re-negotiations), these can be traced by the observer.

In addition, the choice of Brazil, Italy and the United States to compose the set of countries under study was motivated by (i) the significant number of cases and deaths in each country (WHO, 2020), (ii) the political difficulty in dealing with the situation of the new coronavirus (Greer, King, Fonseca \& Peralta-Santos, 2020), (iii) the illustration of different realities, localities and temporalities of knowledge and action on the COVID-19 pandemic (Pisano, Sadun \& Zanini, 2020). Therefore, in spite of being extreme cases of virus proliferation, these cases allowed an analysis of the relational systems in (dis) arrangement, which brought a unique theorizing potential. The previous relations that were stabilized and invisible to the observer, now can be addressed in innovative explanatory processes.

Initially, to cover the space-time path of the virus, we included the Republic of China in our study. However, since the state controls the media and restricts the access to direct speech of its representatives on official Chinese government websites (unlike the other countries analyzed), we excluded this country from our analysis.

In terms of data collection, we analyzed the official statements of the leader of each country, as well as interviews with media outlets and posts on their official social media accounts. Based on the ANT, we understand these representatives as spokespersons. Therefore, they are not actors (in the individual, autonomous and voluntaristic sense), but the effects of numerous previous translations, which were (more or less) stabilized. In Callon and Latour (1981)'s words, these representatives are "micro-actors sitting on many black boxes" (Callon \& Latour, 1981, p. 286), in which multiple previous socio-technical relations became a matter of indifference to their participants.

The official pronouncements were accessed through the official websites and social media accounts (e.g., twitter and youtube) of each government, which present videos and transcripts of the statements in full. As inclusion criteria, we considered the events (posts, interviews and statements) directly and expressly related to the terms new coronavirus, pandemic and/or COVID-19. The time frame of the study begins on January 21, 2020 - with the first diagnosis of COVID-19 in one of the countries surveyed (United States) - and extends until May 20, 2020, based on the theoretical saturation of the phenomenon to be explained, since no new theoretical insights have emerged after this period. Data analysis based on ANT is a way of engagement with the world (Bussular, Burtet \& Antonello, 2019), and involves recognizing the entanglement of relations that are established between actants. For these reasons, we do not conduct data analysis guided by structuralist methods of language (e.g., narratives or discourse). These techniques end up prioritizing the speeches of human actors, giving little space for theorizations that recognize non-humans and the mediated effect of their participation. Therefore, without limiting ourselves to a static and decontextualized analysis of the statements (see Rantaraki \& Vaara, 2017), we are interested in understanding the tangle of heterogeneous relationships that are expressed through them. We elaborated on the following box (Box 1), the details of the data analyzed in this period: 
Box 1

Data sources (Jan. 21, 2020 - May 20, 2020)

\begin{tabular}{|l|c|c|c|}
\hline \multicolumn{1}{|c|}{ Data Sources } & Brazil & Italy & United States \\
\hline Leader's Official announcements to the nation & 8 & 19 & 3 \\
\hline Posts in social media & 230 & 138 & 237 \\
\hline Interviews and press conferences & 11 & 17 & 53 \\
\hline
\end{tabular}

Source: Elaborated by the authors.

Based on the material gathered, the data analysis was conducted thematically and inductively (e.g., Alcouffe et al., 2008), in which the categories themselves emerge from the empirical data throughout the process. From the ANT, the flow of association (relations) is only traceable when it is in motion (Latour, 2005); therefore, the analytical focus is on transformation and not stability (Camillis \& Antonello, 2016). Specifically, based on the translation perspective, we were particularly attentive (sensitive) in (i) understanding how leaders of the researched countries sought to speak on behalf of the new-coronavirus, (ii) perceiving the changes in posture and direction of human actors concerning the roles and behaviours previously enunciated (interested) to the non-human actant, (iii) understanding the dimension of action/participation of the new coronavirus to the detriment of the offensives in silencing it (speaking on its behalf).

Finally, we carried out the analysis and theorization jointly among the countries, in which not necessarily all critical elements are compared pair by pair (i.e. comparative case analysis). In this study, theorization emerged from the synthesized analysis of the joint changes in these localities due to the participation of the non-human (i.e. new coronavirus) and the ongoing translation process. Thus, all the information gathered, even the most (possibly) inexpressive social media post, for example, provided us with a range of entities and relations to explain the whys and wherefores of the courses of action.

\section{The new coronavirus in a nutshell}

The first cases of infection by the new coronavirus were identified in the Chinese province of Wuhan, capital of Hubei, in December 2019. The Corona Virus Disease - COVID-19 is a viral disease caused by the SARS-CoV-2 - Severe Acute Respiratory Syndrome of Coronavirus 2, and mainly affects the human respiratory system. On January 30, 2020, given the fast rate of transmission, the characteristics of its spread and the complications of the illness, the WHO decreed Public Health Emergency of International Importance, the highest alert according to the International Health Regulations (WHO, 2020).

Although the new coronavirus had already been in wide circulation, it was only on February 11, 2020, that the disease caused by it was technically classified and called COVID-19. On March 11, 2020, the situation of a pandemic - the spread of a new disease worldwide - was decreed by the WHO. With the exponential emergence of confirmed cases and deaths in many countries, the WHO recommended social distancing as a strategy to contain the virus spread in the face of the real possibilities of collapse in various health systems through all over the world. Besides, effects have been noted in the economic, sports, social, political and, above all, the health systems (Pan American Health Organization, 2020). These effects were felt because there is no definitive treatment or a vaccine.

The first Italian case of COVID-19 was registered on January 31, 2020, in Codogno in Lombardy, on the northern region of the country (Pisano et al., 2020). Initially, this region was the most affected, later spreading to other Italian cities. A similar situation was seen in the United States, which confirmed its first case some days earlier, on January 24, 2020 (Centers for Disease Control and Prevention [CDC], 2020). In both countries, those infected passed through Wuhan, the epicentre of the pandemic in China. In Brazil, the first case was confirmed on February 26, 2020, in a 61-year-old man who visited the region of Lombardy, Italy (Ministério da Saúde, 2020).

In this context, we explore how leaders from these three countries sought to impose an identity and a role on the new coronavirus, as we will discuss in the following section. 


\section{RESULTS}

In this section, we present a longitudinal analysis of the movements and relational transformations among the actors involved in the network, with a particular focus on the attempts of government leaders in Brazil, Italy and the United States to assume the voice of the new coronavirus (silent actor in Callon, 1986) and speak on its behalf. This analysis allowed us to theorize on the process of disinteressement. In this process, we detailed the human actors' negotiation difficulty (and the relational networks that sustain them) in imposing a "stabilized" role for the new coronavirus and mobilizing it.

We noticed four movements of the studied authorities in imposing a definitive role on the new coronavirus, namely: (i) subjugation, (ii) domestication, (iii) accommodation, (iv) embodiment. It should be noted that these movements are analytical efforts (Whittle \& Spicer, 2008) and, therefore, are not objectively separated in reality, since they nestle, complement and impact each other.

The first movement, called subjugation ${ }^{3}$, is temporally aligned with the arrival of the new coronavirus in each country. At this time, few people had been infected and the virus action was (apparently) unproblematic. In other words, the relational network was (more or less) stabilized before the participation of the new coronavirus. In Box 2 we present the main statements of the leaders in this first movement:

Box 2

Subjugation Movement

\begin{tabular}{|c|c|c|c|}
\hline Dimension & USA & Brazil & Italy \\
\hline \multirow{2}{*}{$\begin{array}{l}\text { Subjugate: } \\
\text { Silencing the } \\
\text { non-human }\end{array}$} & $\begin{array}{l}\text { We have it totally under control. It's } \\
\text { one person coming in from China, } \\
\text { and we have it under control. It's } \\
\text { going to be just fine (Donald Trump, } \\
\text { January } 22,2020 \text { ). }\end{array}$ & $\begin{array}{l}\text { Much of what you have there is } \\
\text { much more fantasy, the issue of } \\
\text { the coronavirus, it is not all that } \\
\text { the great media spreads [...] (Jair } \\
\text { Messias Bolsonaro, March 10,2020). }\end{array}$ & $\begin{array}{l}\text { We can reassure all citizens, the } \\
\text { situation is under control (Giuseppe } \\
\text { Conte, January } 30,2020 \text { ). }\end{array}$ \\
\hline & $\begin{array}{l}\text { Looks like by April, you know, in } \\
\text { theory, when it gets a little warmer, } \\
\text { it miraculously goes away (Donald } \\
\text { Trump, February 10, 2020). }\end{array}$ & $\begin{array}{l}\text { I'm not a doctor, I'm not an } \\
\text { infectologist. What I've heard so } \\
\text { far [is that] other flu have killed } \\
\text { more than this one (Jair Messias } \\
\text { Bolsonaro, March 11, 2020). }\end{array}$ & $\begin{array}{l}\text { We confirm that the situation is } \\
\text { under control, we are confident } \\
\text { that we will keep both cases under } \\
\text { control. The Italians can lead a } \\
\text { normal life (Giuseppe Conte, } \\
\text { February 01, 2020). }\end{array}$ \\
\hline
\end{tabular}

Source: Data from statements, postings and interviews.

From Box 2, we can observe that there is a direct (not necessarily intentional) attempt to silence the virus, speak on its behalf, and maintain the relative stability of the network in question. The leaders tried to: (i) minimize the virus action, for example, "other colds have killed more" or "is much more fantasy", (ii) impose a (brief) duration on it, as in the passage "in April [...] miraculously disappears", and (iii) maintain the convergence and stability of the network, as in "the Italians can lead a normal life" or even "everything is under control".

The role of 'reassuring' and 'maintaining stability', performed by human actors, complements the movement of subjugation. In this case, the offensives seek to make the virus action a matter of indifference or irrelevance and to keep the relational geometry unchanged, with little or no movement (action) of human actors.

However, the new coronavirus maintained its trajectory of expansion (infection), with the increase of its local transmission ${ }^{4}$ and the first cases of death. In this process, we verified the leaders second movement, which we called domestication (see Box 3 ).

\footnotetext{
${ }^{3}$ We adopted the label subjugation in reference of the process where the freedom of one entity is directed narrowly and in a self-disciplined fashion (see Knights \& Willmott, 1989).

${ }^{4}$ When contamination occurs through contact with someone infected in another country (WHO, 2020).
} 


\section{Box 3}

\section{Domestication Movement}

\begin{tabular}{|c|c|c|c|}
\hline Dimension & USA & Brazil & Italy \\
\hline \multirow{2}{*}{$\begin{array}{l}\text { Domesticate: } \\
\text { controlling the } \\
\text { non-human } \\
\text { under human } \\
\text { supremacy }\end{array}$} & $\begin{array}{l}\text { Some people will have this at a very light } \\
\text { level and won't even go to a doctor or } \\
\text { hospital, and they'll get better. There are } \\
\text { many people like that (Donald Trump, } \\
\text { March 04, 2020). }\end{array}$ & $\begin{array}{l}\text { Rare are the fatal cases of healthy } \\
\text { people under } 40 \text { (Jair Messias } \\
\text { Bolsonaro, March 24, 2020). }\end{array}$ & $\begin{array}{l}\text { We have adopted, we have always said } \\
\text { and I confirm, a line of extreme caution. } \\
\text { We are, among the western countries } \\
\text { where obviously the standards of health } \\
\text { care are the highest, we are the country } \\
\text { that has adopted the most [...] most } \\
\text { secure measures (Giuseppe Conte, } \\
\text { February 22, 2020). }\end{array}$ \\
\hline & $\begin{array}{l}\text { We're prepared, and we're doing a } \\
\text { great job with it. And it will go away. } \\
\text { Just stay calm. It will go away (Donald } \\
\text { Trump, March 10, 2020). }\end{array}$ & $\begin{array}{l}\text { [...] if I were contaminated by the virus, } \\
\text { [I] wouldn't have to worry, I wouldn't } \\
\text { feel anything or be, at most, affected } \\
\text { by a little flu or a little cold [...] (Jair } \\
\text { Messias Bolsonaro, March } 24,2020 \text { ). }\end{array}$ & $\begin{array}{l}\text { Our health system is excellent, our } \\
\text { precautionary measures are of the } \\
\text { utmost rigour and we trust that, by } \\
\text { virtue of the combination of a health } \\
\text { system of excellence and a line of } \\
\text { health policy of the utmost rigour, } \\
\text { in the coming days, we will produce } \\
\text { a containment effect of the virus } \\
\text { (Giuseppe Conte, February } 25,2020 \text { ). }\end{array}$ \\
\hline
\end{tabular}

Source: Data from statements, postings and interviews.

In this second movement, called domestication in reference to Callon's term (see e.g., Callon, 1986; Munro, 2012), we noticed that the leaders sought to demonstrate control over the virus, instead of denying its effects (as in the subjugation movement). Through Box 3 we verified (i) the attempt for segmenting the virus action regarding the intensity of its effects on people, such as: "some people will have it at a very light level", "rare are the fatal cases" or "if it was affected by the virus, [...] it would feel nothing or would be when very much affected by a little flu or little cold".

In this second movement, in regards to human (re)actions, instead of a question of indifference or irrelevance (as in the previous moment), the leaders (ii) have demonstrated the need for preparation and action to deal with the virus, for example, "We are prepared" or even "[...] we adopt [...] a line of extreme caution". That is, unlike the subjugation movement, there is a need for real mobilization by human actors to contain the virus. The human action, in this second movement, is showed as planned, rational, programmed and then implemented, indicating total normality of leaders discourse to the rational logic of problem-solving.

A third element that we identified in this movement was (iii) the attempt to signify the argument of human supremacy, in the sense that, even with real effects, they (effects) are being solved by intentional human action, such as, "we're doing a great job with it. And it will go away" or "we will produce a containment effect of the virus". In other words, there is the (attempted) domestication (Callon, 1986), which is given by the intentional action of human beings that exercise their power over non-humans (e.g., animals).

In a third period, the virus is spread in community transmission ${ }_{5}$, when it is no longer possible to trace the chain of contamination, and cases of infection and death grow geometrically. In this process, we identified the movement nominated as accommodation, which we present in Box 4:

${ }^{5}$ Mode of virus circulation in which authorities can no longer trace the first patient who originated the chains of infection, or when it involves more than five generations of people (WHO, 2020) 
Box 4

Accommodation Movement

\begin{tabular}{|c|c|c|c|}
\hline Dimension & USA & Brazil & Italy \\
\hline \multirow[t]{2}{*}{$\begin{array}{l}\text { Accommodate: } \\
\text { restraining the } \\
\text { non-human } \\
\text { in fear of the } \\
\text { human impact }\end{array}$} & $\begin{array}{l}\text { This is the most aggressive and } \\
\text { comprehensive effort to confront } \\
\text { a foreign virus in modern } \\
\text { history. I am confident that by } \\
\text { counting and continuing to take } \\
\text { these tough measures, we will } \\
\text { significantly reduce the threat to } \\
\text { our citizens, and we will ultimately } \\
\text { and expeditiously defeat this virus } \\
\text { (Donald Trump, March } 11,2020 \text { ). }\end{array}$ & $\begin{array}{l}\text { I'm aware of my responsibility, } \\
\text { the virus came from outside to } \\
\text { inside. We have to find a solution } \\
\text { to minimize the consequences of } \\
\text { the virus here in Brazil. Are people } \\
\text { going to die? People are going to } \\
\text { die! As some people have (already) } \\
\text { died [...] (Jair Messias Bolsonaro, } \\
\text { March 30, 2020). }\end{array}$ & $\begin{array}{l}\text { We will evaluate extraordinary } \\
\text { measures (Giuseppe Conte, } \\
\text { February 22, 2020). }\end{array}$ \\
\hline & $\begin{array}{l}\text { This is a very contagious virus. It's } \\
\text { incredible. But it's something that } \\
\text { we have tremendous control over } \\
\text { (Donald Trump, March 15, 2020). }\end{array}$ & $\begin{array}{l}\text { The virus is a reality, there is no } \\
\text { vaccine against it yet or medicine } \\
\text { with scientifically proven efficacy, } \\
\text { although hydroxychloroquine } \\
\text { seems quite effective (Jair Messias } \\
\text { Bolsonaro, March 31, 2020). }\end{array}$ & $\begin{array}{l}\text { Our habits need to change, they } \\
\text { need to change now, we all need } \\
\text { to give something up for the good } \\
\text { of Italy [...] (Giuseppe Conte, March } \\
09,2020 \text { ). }\end{array}$ \\
\hline
\end{tabular}

Source: Data from statements, postings and interviews.

In this third movement, the leaders no longer can deny, minimize or have plain control (intentional and unproblematic) over the new coronavirus (e.g., subjugation and domestication movements). Therefore, it is necessary to accommodate it, in the sense of (i) managing its (undeniable) effects, as in: "We have to find a solution to minimize the consequences of the virus here in Brazil".

Also, we realized that in opposition to many of the statements made by these same leaders in the previous movements, (ii) there is a narrative that begins to highlight the strength and power of the new coronavirus, such as "This is a very contagious virus" or "The virus is a reality, there is no vaccine against it yet". And, consequently, (iii) the search for showing a (re)action from this "reality", as in "Let's evaluate extraordinary measures" or "This is the most aggressive and comprehensive effort to face a foreign virus in modern history".

We still verified that the relational network before the virus participation has been destabilized, requiring (iv) change in the individuals (human beings of the network) behaviour patterns, for example, "Our habits need to change, they need to change now, we all need to give something up". And, therefore, the accommodation movement is characterized by numerous efforts to contain the action and spread of the virus in fear of its impact on people and their network (e.g., families, organizations, governments, populations).

Finally, given the recalcitrance of the new coronavirus in remaining on its expanding trajectory (an increase of infections, crowding health units and growth of deaths), we notice a fourth movement in which the action of the virus becomes embodied (in reference to Barad, 2003 posthumanist view) to extreme or uncontrollable situations, as detailed in Box 5. 


\section{Box 5}

\section{Embodiment Movement}

\begin{tabular}{|c|c|c|c|}
\hline Dimension & USA & Brazil & Italy \\
\hline \multirow{3}{*}{$\begin{array}{l}\text { Embody: } \\
\text { incorporating } \\
\text { the non-human } \\
\text { to things to } \\
\text { (re)frame its } \\
\text { participation }\end{array}$} & $\begin{array}{l}\text { We have an invisible enemy (Donald } \\
\text { Trump, March 16, 2020). }\end{array}$ & $\begin{array}{l}\text { [...] now we face the greatest challenge } \\
\text { of our generation (Jair Messias } \\
\text { Bolsonaro, March 31, 2020). }\end{array}$ & $\begin{array}{l}\text { It's the most difficult crisis the country } \\
\text { is experiencing after World War II } \\
\text { (Giuseppe Conte, March 21, 2020). }\end{array}$ \\
\hline & $\begin{array}{l}\text { I see it as, in a sense, a wartime president } \\
\text { (Donald Trump, March 18, 2020). }\end{array}$ & $\begin{array}{l}\text { "I would like, first of all, to show } \\
\text { solidarity with the families who have } \\
\text { lost their loved ones in this war that } \\
\text { we are facing (Jair Messias Bolsonaro, } \\
\text { April 08, 2020). }\end{array}$ & $\begin{array}{l}\text { Today we have decided to take } \\
\text { another step, the decision taken } \\
\text { by the government is to close in all } \\
\text { national territory, all productive activity } \\
\text { that is not strictly necessary, crucial, } \\
\text { indispensable for guaranteeing essential } \\
\text { goods and services (Giuseppe Conte, } \\
\text { March } 21,2020 \text { ). }\end{array}$ \\
\hline & $\begin{array}{l}\text { With the courage of our doctors and } \\
\text { nurses, with the skill of our scientists } \\
\text { and innovators, with the determination } \\
\text { of the American People, and with the } \\
\text { grace of God, WE WILL WIN THIS WAR. } \\
\text { When we achieve this victory, we will } \\
\text { emerge stronger and more united than } \\
\text { ever before! (Donald Trump, March } \\
28,2020 \text { ). }\end{array}$ & $\begin{array}{l}\text { There is no scientific evidence yet, } \\
\text { but it is being monitored and used in } \\
\text { Brazil and the world. However, we are } \\
\text { at war: "Worse than being defeated } \\
\text { is the shame of not having fought". } \\
\text { (Jair Messias Bolsonaro, May 20, 2020). }\end{array}$ & $\begin{array}{l}\text { Right now we must resist, because } \\
\text { only in this way will we be able to } \\
\text { protect ourselves and the people we } \\
\text { love (Giuseppe Conte, March } 21,2020 \text { ). }\end{array}$ \\
\hline
\end{tabular}

Source: Data from statements, postings and interviews.

From Box 5 we can note that (i) to the virus is given a skilled role, as in "we have an invisible enemy", or even "the greatest challenge of our generation". Besides, (ii) the situation is described by war circumstances in a metaphorical-comparative way "It is the most difficult crisis [...] after the Second World War", or straight - "we are at war"; "in this war we are facing". The seriousness of the situation, represented in these quotes, is now recognized by the leaders faced with the impossibility of controlling and containing the expansion of the non-human (previous movements), suggest the need to "resist [...] to protect ourselves and the people we love".

In terms of the network, we identified that (iii) the transformation in the system is now attributed to the causal action of the virus. In other words, as relational stability was compromised, it requires an effort, such as "closing in all national territory, all productive activity" to reach a new stage of stabilization (also provisional and fragile). In this case, it is not the end of the translation process, but another offensive of interestment (Akrich et al., 2002; Callon, 1986), which, in the face of the situation, (iv) demands the participation of divine forces (e.g., "with the grace of God") or superhuman forces (e.g., "a wartime president").

In this fourth movement, we describe how human actors began to embody the action of the virus into extreme phenomena to justify their positions, their roles and their actions. This form of the inscription is an alternative way of interest regarding the impossibility of silencing the virus in the translation process and its resistance to the roles that were (pre)determined previously.

Finally, it should be emphasized that the theoretical process of disinterest should not be read as a direct exchange or negotiation - in terms of cause and consequence - between human (presidents) and non-human (the virus), since there is a greater multiplicity of networks, actants and interests at stake. However, the case of the new coronavirus gives us elements to describe how a non-human micro actor destabilizes, affronts, dismantles, and disallows an entire network crystallized around human macro actors. That is, as in David and Goliath, metaphorically; power, size, and strength are not enough to define the designees of action, which gain tortuous paths, unexpected relational effects, and undetermined roles and identities. 


\section{DISCUSSION}

By not being interested in the offensives of the leaders, the new coronavirus showed that, by disregarding the action of non-human actants (in analytical symmetry) in the network, only a partial and limited understanding of the phenomenon could be achieved. In the period analyzed, this partiality became clear in the failure of the translation process in which the leaders tried, in multiple attempts, to speak in the name of the virus, but were forced (by the relations triggered by the virus itself), to change their discourses and the course of their actions.

The recalcitrance of the non-human actant becomes evident when human actors (those who have a voice in the network) need to reconsider their speech and actions, and/or redo the previously (even if partially) stabilized relations due to the intolerance, disobedience or permanence (without any attribution of intention or will) of the effects of the new coronavirus in the relational system. In Box 6 we detail the trials to interest the new actant throughout its trajectory in the network. The disinteressement shows that, despite the multiple offensives of the macro actors, the participation of the new actant has not been stabilized. That is, it has not become a matter of indifference.

\section{Box 6}

Disinteressment in the translation process

\begin{tabular}{|c|l|l|}
\hline Movement & \multicolumn{1}{|c|}{ Goal } & \multicolumn{1}{c|}{ Trials of interessment } \\
\hline Subjugation & $\begin{array}{l}\text { Silence another } \\
\text { actant. }\end{array}$ & $\begin{array}{l}\text { (i) Minimize the effects of the new actant in the network. } \\
\text { (ii) Impose a duration on the new actant's participation. } \\
\text { (iii) Maintain the stability and convergence of the network. }\end{array}$ \\
\hline Domestication & $\begin{array}{l}\text { Control another } \\
\text { actant, keeping } \\
\text { authority. }\end{array}$ & $\begin{array}{l}\text { (i) Segment and bound the new actant's participation. } \\
\text { (ii) Demonstrate preparation and knowledge to deal with the effects of the } \\
\text { participation of the new actant. } \\
\text { (iii) Give meaning and reinforce the authority of the human actant over the network. }\end{array}$ \\
\hline \multirow{2}{*}{$\begin{array}{l}\text { Restrict the } \\
\text { performance of } \\
\text { another actant. }\end{array}$} & $\begin{array}{l}\text { (i) Manage and reduce the effects of the undeniable participation of the new actant. } \\
\text { (ii) Emphasize the power of the new actant over the network, demonstrating the } \\
\text { difficulty in dealing with it. } \\
\text { (iii) Show appropriate (re)actions to deal with a new relational reality. } \\
\text { (iv) Change previous behaviour patterns of actants in the network. }\end{array}$ \\
\hline $\begin{array}{l}\text { Incorporate the new } \\
\text { actant to other actants } \\
\text { or events to (re)frame } \\
\text { its role and/or identity } \\
\text { and justify its effects. }\end{array}$ & $\begin{array}{l}\text { (i) Assign a skilled role to the new actant. } \\
\text { (ii) Compare and relate the effects of the participation of the new actant with } \\
\text { circumstances of great magnitude. } \\
\text { (iii) Incorporate unwanted effects as direct causal actions of the new actant. } \\
\text { (iv) Demand the participation of extreme and superior forces to deal with the } \\
\text { situation, making it "humanly unmanageable". }\end{array}$ \\
\hline
\end{tabular}

Source: Elaborated by the authors.

In theoretical terms, the process of disinteressement is based on the perception that the non-human (i.e. new coronavirus) (i) is active in terms of participation in the network since it even alters human plans and actions in the system, and (ii) has recalcitrance since it has resisted (out of disinterest) the roles imposed on it. We can understand it as two idealistic poles of participation (action) of the non-human actant since, in reality, these effects are not "pure" because they are aligned and nested with other effects of the multiple heterogeneous that assemble the network in question. Therefore, these poles (active participation and recalcitrance) have been designed in didactic character and cannot be taken as an intentional, intrinsic and non-problematic capacity of the non-human actor. As Lorino (2018, p. 81) reminds us "there cannot be any theory of sociomateriality without a theory of mediated action". So, the effects of action are distributed (Rammert, 2012; Sayes, 2014). 
The process of disinteressement extends the translation literature that does not follow "well-behaved paths" from problematization to mobilization. In Box 7 we portray the "unsuccessful" translation processes. The term unsuccessful is used in reference to translation processes that have not reached the stage of convergence and irreversibility indicated for the mobilization of actors (Cochoy, 2014).

\section{Box 7}

Mechanism of/for unsuccessful translation

\begin{tabular}{|c|c|l|}
\hline $\begin{array}{c}\text { Mechanisms of } \\
\text { unsuccessful" } \\
\text { translations }\end{array}$ & Authors & \multicolumn{1}{c|}{ Definition } \\
\hline Counter-enrolment & $\begin{array}{c}\text { Vickers and Fox } \\
(2005)\end{array}$ & $\begin{array}{l}\text { Adispute between actants to define the problematization } \\
\text { around which the network will be mobilized. }\end{array}$ \\
\hline Dissidence & $\begin{array}{l}\text { Bergstrom and } \\
\text { Diedrich (2011) }\end{array}$ & $\begin{array}{l}\text { Some actants do not follow the paths (roles and } \\
\text { identities) that have been (relatively) attributed to them. }\end{array}$ \\
\hline Disentanglement & $\begin{array}{l}\text { Greener (2006) } \\
\text { actants try to disassociate themselves from the 'made } \\
\text { actor' that mobilized them previously. }\end{array}$ \\
\hline Disinteressement & This study & $\begin{array}{l}\text { Actants resist the offensives of another (set of) actant(s) } \\
\text { attempting to impose them specific roles or identities. }\end{array}$ \\
\hline
\end{tabular}

Source: Elaborated by the authors.

In the process of disinteressement even if all the actors are aligned around a problem, the interessement for further mobilization is never achieved. The roles and identity attributed to the non-human actant are annulled by its recalcitrance in maintaining its flow of action, without accepting the "obligatory points of passage" discursively imposed by the macro actors of the study.

The mechanism of disinteressement differs from other theorizations in which there is also an active process of negotiation and manipulation of interests (e.g., counter-enrolment), because, in this case, it is the recalcitrance of the non-human actant who, out of disinterest, does not play the role interested by human actors. Besides, it differs from theorizations that detail the destabilization and divergence in the network of relations (e.g., disentanglement and dissidence), since, in this case, no agreement or alignment was reached, so that it could later be undone or disarranged.

In addition, in analytical symmetry, rather than a successful translation process in which human actors speak on behalf of others - human and non-human (e.g., Hawkins, 2015), our study demonstrated how the non-human actant (i.e. the new coronavirus) resisted and disordered the claims to control it. Thus, the effects arising from the participation of the non-human actor, by "infelicitous conditions" (Latour, 2013), generate unwanted trajectories, deconstruct linear narratives, change social behaviours and disallow those who want to speak on its behalf.

\section{CONCLUSION}

We used the sociology of translation to understand the relational processes with the purpose to reveal the participation of non-humans in the networks that are established in these processes. In the COVID-19 pandemic situation, in which the new coronavirus assumed a unique role for a non-human actor, we described how leaders from Brazil, Italy and the United States sought to take the voice of the new coronavirus, establish a well-behaved role and speak on its behalf.

The period of rupture of the relational network covered by this study has exposed the attempts of human actors to assume authority over the "new entrant". Regardless of whether some convergence and irreversibility (Cochoy, 2014) can be reached in the future, it will already be transformed by the process of disinteressement that brought the reality into being.

In terms of contribution, by suggesting the process of disinteressement, we are adding new theoretical elements to the few studies that deal with resistance in the translation process (as indicated by Whittle \& Spicer, 2008). Furthermore, we narrated the participation of the non-human actor, without attributing to it human capacities of intentionality, freedom, voluntarism or reflexivity (Sayes, 2014) and without legitimizing the hegemonic powers in acting (Whittle \& Spicer, 2008). However, even 
without falling into absurd descriptions (McLean \& Hassard, 2004), we verified that the virus is more than "mere object" (Latour, 2000), because it ignored the offensives in silencing it, opposed the allegations that minimized its effects, and refused to interrupt its trajectory in the face of human efforts in imposing a determined role on it.

Concerning a future agenda, although we have explicitly dealt with the leaders' utterances, the case brings to analysis a variety of human (e.g., media agents, scientists, politicians, opportunists) and non-human (tests, vaccines, protective devices, technologies), with effects on the organization of different social systems (e.g., families, companies, governments). It becomes then a representative case in its depth and an extreme one in its effects for new theorizations. As opposed to the cohesion of the contexts under study, which brought explanatory power to our theorization, future efforts could be directed to the study of interessement/disinteressement of the new coronavirus in contexts in which its participation has been translated in ways to minimize (relatively) its effects.

Finally, we believe that the new coronavirus case can mobilize organization studies for more processual and post-humanist perspectives (see Blok et al., 2020; Camillis \& Antonello, 2016). In particular, by decentralizing the human and positioning it among multiple and heterogeneous actants, we can work on the non-human participation and the distributed agency (Rammert, 2012). The human deflation in social and organizational theories, given the analyzed case and the results presented, goes beyond the analytic-symmetrical question and becomes an urgent moral issue (Latour, 2000). Many different types of non-humans participate and represent networks in organizational systems (Jensen, Sandström \& Helin, 2009); therefore, ignoring them in our theoretical and explanatory processes seems to be, morally, a way of ignoring our role as social theorists.

\section{ACKNOWLEDGEMENTS}

This study was financed in part by the Coordenação de Aperfeiçoamento de Pessoal de Nível Superior - Brasil (CAPES) Finance Code 001 (Eduardo Guedes Villar and Rodrigo Seefeld). We thank as well the members of the Strategy and Decision-Making Research Group at the Federal University Paraná for contributions in previous versions of the manuscript. 


\section{REFERENCES}

Akrich, M., Callon, M., Latour, B., \& Monaghan, A. (2002). The key to success in innovation part I: The art of interessement. International Journal of Innovation Management, 6(2), 187-206. Retrieved from https://doi.org/10.1142/S1363919602000550

Alcouffe, S., Berland, N., \& Levant, Y. (2008). Actor-networks and the diffusion of management accounting innovations: A comparative study. Management Accounting Research, 19(1), 1-17. Retrieved from https://doi.org/10.1016/j.mar.2007.04.001

Ali, I. (2020). The COVID-19 Pandemic: Making Sense of Rumor and Fear. Medical Anthropology, 39(5), 376-379. Retrieved from https:// doi.org/10.1080/01459740.2020.1745481

Barad, K. (2003). Posthumanist performativity: Toward an understanding of how matter comes to matter. Signs, 28(3), 801-831. Retrieved from https://doi.org/10.1086/345321

Bergström, O., \& Diedrich, A. (2011). Exercising social responsibility in downsizing: Enrolling and mobilizing actors at a Swedish high-tech company. Organization Studies, 32(7), 897-919. Retrieved from https://doi.org/10.1177/0170840611407019

Blok, A., Farias, I., \& Roberts, C. (2020). The Routledge Companion to Actor-Network Theory. Abingdon, UK: Routledge.

Bruce, K., \& Nyland, C. (2011). Elton Mayo and the deification of human relations. Organization Studies, 32(3), 383-405. Retrieved from https://doi.org/10.1177/0170840610397478

Bussular, C. Z., Burtet, C. G., \& Antonello, C. S. (2019). The actornetwork theory as a method in the analysis of Samarco disaster in Brazil. Qualitative Research in Organizations and Management, 15(2), 176-191. Retrieved from https://doi.org/10.1108/QROM-04-2017-1520

Callon, M. (1986). Some elements of a sociology of translation: domestication of the scallops and the fishermen of St Brieuc Bay. The Sociological Review, 32(S1), 196-233. Retrieved from https:// doi.org/10.1111/j.1467-954X.1984.tb00113.x

Callon, M., \& Latour, B. (1981). Unscrewing the big Leviathan: How actors macrostructure reality and how sociologists help them to do so. In K. Knorr-Cetina, \& A. V. Cicourel (Eds.), Advances in Social Theory and Methodology (RLE Social Theory): Toward an Integration of Micro- and Macro-Sociologies. Abingdon, UK: Routledge.

Callon, M., \& Law, J. (1982). On interests and their transformation enrolment and counter-enrolment. Social Studies of Science, 12(4), 615-625. Retrieved from https://www.jstor.org/stable/284830

Callon, M., \& Law, J. (1997). After the individual in society: Lessons on collectivity from science, technology and society. Canadian Journal of Sociology, 22(2), 165-182. Retrieved from https://doi. org/10.2307/3341747

Camillis, P. K. D., \& Antonello, C. S. (2016). From translation to enactment: contributions of the Actor-Network Theory to the processual approach to organizations. Cadernos EBAPE.BR, 14(1), 61-82. Retrieved from https://doi.org/10.1590/1679-395131412

Cavalcanti, M. F. R., \& Alcadipani, R. (2013). Organizations as processes and Actor-Network Theory: John Law's contribution to Organizational
Studies. Cadernos EBAPE.BR, 11(4), 556-568. Retrieved from https:// doi.org/10.1590/S1679-39512013000400006

Centers for Disease Control and Prevention. (2020). First Travelrelated Case of 2019 Novel Coronavirus Detected in United States. Retrieved from https://www.cdc.gov/media/releases/2020/p0121novel-coronavirus-travel-case.html

Cochoy, F. (2014). A theory of 'agencing': On Michel Callon's contribution to organizational knowledge and practice. In P. S. Adler, P. Du Gay, G. Morgan \& M. I. Reed (Eds.), The Oxford handbook of sociology, social theory, and organization studies: Contemporary currents (pp. 106-124). Oxford, UK: Oxford University Press.

Dambrin, C., \& Robson, K. (2011). Tracing performance in the pharmaceutical industry: Ambivalence, opacity and the performativity of flawed measures. Accounting, Organizations and Society, 36(7), 428-455. Retrieved from https://doi.org/10.1016/j.aos.2011.07.006

Greener, I. (2006). Nick Leeson and the collapse of Barings Bank: Socio-technical networks and the 'Rogue Trader'. Organization, 13(3), 421-441. Retrieved from https://doi.org/10.1177/1350508406063491

Greer, S. L., King, E. J., Fonseca, E. M., \& Peralta-Santos, A. (2020). The comparative politics of COVID-19: The need to understand government responses. Global Public Health, 15(9), 1413-1416. Retrieved from https://doi.org/10.1080/17441692.2020.1783340

Gudi, S. K., \& Tiwari, K. K. (2020). Preparedness and lessons learned from the novel coronavirus disease. The International Journal of Occupational and Environmental Medicine, 11(2), 108-112. Retrieved from https://doi.org/10.34172/ijoem.2020.1977

Gunia, A. (2020, March 23). Will the Coronavirus Ever Go Away? Here's What One of the WHO's Top Experts Thinks. Time. Retrieved from https://time.com/5805368/ will-coronavirus-go-away-world-health-organization/

Hawkins, B. (2015). Ship-shape: materializing leadership in the British Royal Navy. Human Relations, 68(6), 951-971. Retrieved from https:// doi.org/10.1177/0018726714563810

Jensen, T., Sandström, J., \& Helin, S. (2009). Corporate codes of ethics and the bending of moral space. Organization, 16(4), 529545. Retrieved from https://doi.org/10.1177/1350508409104507

Knights, D., \& Willmott, H. (1989). Power and subjectivity at work: From degradation to subjugation in social relations. Sociology, 23(4), 535558. Retrieved from https://doi.org/10.1177/0038038589023004003

Latour, B. (1992). Where Are the Missing Masses? The Sociology of a Few Mundane Artifacts. In W. Bijker, T. Hughes, \& T. Pinch (Eds.), The social construction of technological systems (pp. 1-34). London, UK: MIT Press.

Latour, B. (2000). When things strike back: a possible contribution of 'science studies' to the social sciences. The British Journal of Sociology, 51(1), 107-123. Retrieved from https://doi. org/10.1111/j.1468-4446.2000.00107.x

Latour, B. (2004). Politics of nature: How to bring the sciences into democracy. Cambridge, MA: Harvard University Press. 
Latour, B. (2005). Reassembling the social: An introduction to actor-network theory. Oxford, UK: Oxford University Press.

Latour, B. (2013). An Inquiry into Modes of Existence: An Anthropology of the Moderns. Cambridge, MA: Harvard University Press.

Latour, B. (2014). Agency at the Time of the Anthropocene. New Literary History, 45(1), 1-18. Retrieved from https://www.jstor.org/ stable/24542578

Law, J. (1992). Notes on the theory of the actor-network: Ordering, strategy, and heterogeneity. Systems practice, 5(4), 379-393. Retrieved from https://doi.org/10.1007/BF01059830

Law, J., \& Singleton, V. (2005). Object lessons. Organization, 12(3), 331-355. Retrieved from https://doi.org/10.1177/1350508405051270

Lee, N., \& Hassard, J. (1999). Organization unbound: Actor-network theory, research strategy and institutional flexibility. Organization, 6(3), 391-404. Retrieved from https://doi.org/10.1177/135050849963002

Luoma-aho, V., \& Paloviita, A. (2010). Actor-networking stakeholder theory for today's corporate communications. Corporate Communications, 15(1), 49-67. Retrieved from https://doi. org/10.1108/13563281011016831

McLean, C., \& Hassard, J. (2004). Symmetrical absence/symmetrical absurdity: Critical notes on the production of actor-network accounts. Journal of Management Studies, 41(3), 493-519. Retrieved from https://doi.org/10.1111/j.1467-6486.2004.00442.x

Ministério da Saúde. (2020). COVID-19: Painel Coronavírus. Retrieved from https://covid.saude.gov.br/

Munro, R. (2012). Agency and "worlds" of accounts: Erasing the trace or rephrasing the action? In J. Passoth, B. Peuker, \& M. Schillmeier (Eds.), Agency without Actors? New Approaches to Collective Action (pp. 67-86). London, UK: Routledge.

O Antagonista. (2020, May 07). Para Mandetta, Bolsonaro queria ministro "mais alinhado com a visão econômica". Retrieved from https://www.oantagonista.com/brasil/para-mandetta-bolsonaroqueria-ministro-mais-alinhado-com-a-visao-economica

Pan American Health Organization. (2020). Fact Sheet VOCID-19 (disease caused by the new coronavirus). Retrieved from https://www.paho.org/bra/index.php?option=com content\&view=article\&id=6101: covid19\& 1 temid $=875$

Pisano, G. P., Sadun, R., \& Zanini, M. (2020, March 27). Lessons from Italy's response to coronavirus. Harvard Business Review. Retrieved from https://hbr.org/2020/03/lessons-from-italys-response-to-coronavirus

Rammert, W. (2012). Distributed agency and advanced technology: or how to analyze constellations of collective inter-agency. In J. Passoth,
B. Peuker, \& M. Schillmeier (Eds.), Agency without Actors? New Approaches to Collective Action (pp. 89-112). London, UK: Routledge.

Rantakari, A., \& Vaara, E. (2017). Narratives and processuality. In A. Langley, \& H. Tsoukas (Eds.), The Sage handbook of process organization studies (pp. 271-285). Newcastle Upon Tyne, UK: Sage.

Sayes, E. (2014). Actor-Network Theory and methodology: Just what does it mean to say that non-humans have agency? Social Studies of Science, 44(1), 134-149. Retrieved from https://doi. org/10.1177/0306312713511867

Smith, S., Rose, M., \& Hamilton, E. (2010). The story of a university knowledge exchange actor-network told through the sociology of translation: A case study. International Journal of Entrepreneurial Behavior \& Research, 16(6), 502-516. Retrieved from https://doi. org/10.1108/13552551011082470

Steen, J. (2010). Actor-network theory and the dilemma of the resource concept in strategic management. Scandinavian Journal of Management, 26(3), 324-331. Retrieved from https://doi.org/10.1016/j. scaman.2010.05.003

Tonelli, D. F. (2016). Epistemological origins and affiliations of the Actor-Network Theory: implications for organizational analysis. Cadernos EBAPE.BR, 14(2), 377-390. Retrieved from https://doi. org/10.1590/1679-395141596

Vickers, D., \& Fox, S. (2005). 'Powers in a factory' in Actor-Network Theory and organizing. In B. Czarniawska \& T. Hernes (Eds.), ActorNetwork Theory and Organizing (pp. 129-144). Frederiksberg, Denmark: Copenhagen Business School Press.

Whittle, A., \& Spicer, A. (2008). Is actor network theory critique? Organization Studies, 29(4), 611-629. Retrieved from https://doi. org/10.1177/0170840607082223

Woolgar, S., Coopmans, C., \& Neyland, D. (2009). Does STS mean business? Organization, 16(1), 5-30. Retrieved from https://doi. org/10.1177/1350508408098983

World Health Organization. (2020). WHO Timeline - COVID-19. Retrieved from https://www.who.int/news-room/ detail/27-04-2020-who-timeline---covid-19

Wæraas, A., \& Nielsen, J. A. (2016). Translation theory 'translated': Three perspectives on translation in organizational research International Journal of Management Reviews, 18(3), 236-270. Retrieved from https://doi.org/10.1111/ijmr.12092

Your Content. (2020, March 24). Italian official says there are 10 time more COVID-19 cases than reported. Retrieved from https://www. yc.news/2020/03/24/italian-official-says-there-are-10-time-morecovid-19-cases-than-reported/ 
Eduardo Guedes Villar ORCID: https://orcid.org/0000-0001-5005-4099

Lecturer at the Regional University of Blumenau (FURB); Postdoctoral researcher in Strategy and Organisational Analysis at the Federal University of Parana (UFPR).E-mail: eduardogvillar@gmail.com

\section{Karina De Déa Roglio} ORCID: https://orcid.org/0000-0002-5256-8330

Associate professor of strategic decision-making at the Federal University of Paraná (UFPR); She leaders the Strategy and Decision-Making Research Group at the Federal University of Paraná (UFPR). E-mail: karinaroglio@gmail.com

Marcos Vinícius Pereira Correa

ORCID: https://orcid.org/0000-0002-8132-1097

Lecturer at the State University of Paraná (UNESPAR); Ph.D. in Strategy and Organizational Analysis at Federal University of Paraná (UFPR).

E-mail: marcos.correa15@gmail.com

Rodrigo Seefeld

ORCID: https://orcid.org/0000-0001-5398-8807

Ph.D. student at the Federal University of Paraná (UFPR). E-mail: rodrigoseefeld@gmail.com 